Giving Beyond the Gift 
This page intentionally left blank 


\title{
Giving Beyond the Gift
}

Apophasis and Overcoming Theomania

\author{
ELLIOT R. WOLFSON
}

FORDham UNIVERSity PRESS New York 2014 


\section{Copyright $(2014$ Fordham University Press}

All rights reserved. No part of this publication may be reproduced, stored in a retrieval system, or transmitted in any form or by any meanselectronic, mechanical, photocopy, recording, or any other-except for brief quotations in printed reviews, without the prior permission of the publisher.

Fordham University Press has no responsibility for the persistence or accuracy of URLs for external or third-party Internet websites referred to in this publication and does not guarantee that any content on such websites is, or will remain, accurate or appropriate.

Fordham University Press also publishes its books in a variety of electronic formats. Some content that appears in print may not be available in electronic books.

\section{Library of Congress Cataloging-in-Publication Data}

\section{Wolfson, Elliot R.}

Giving beyond the gift : apophasis and overcoming theomania / Elliot R. Wolfson. - First edition.

pages $\mathrm{cm}$

Includes bibliographical references and index.

ISBN 978-0-8232-5570-2 (cloth : alk. paper) -

ISBN 978-0-8232-557I-9 (pbk. : alk. paper)

I. Jewish philosophy—2oth century. I. Title.

B5800.W65 2014

I8I'.06-dc23 2013034990

Printed in the United States of America

I6 I5 I4 5432 I

First edition 
To the blessed memory

of Michael A. Signer

Altissima quaeque flumina minimo sono labi 
This page intentionally left blank 
Even as the egomaniac does not live anything directly, whether it be a perception or an affection, but reflects on his perceiving or affectionate I and thus misses the truth of the process, thus the theomaniac ... will not let the gift take full effect but reflects instead on that which gives, and misses both. -Martin Buber, I and Thou

But where does the opening come from and how is it given? What speaks in the "It gives"?

—Martin Heidegger, "The End of Philosophy and the Task of Thinking" 
This page intentionally left blank 